\title{
PENERAPAN BRANCH AND BOUND ALGORITHM DALAM OPTIMALISASI PRODUKSI ROTI
}

\author{
Gede Suryawan $^{1 \S}$, Ni Ketut Tari Tastrawati ${ }^{2}$, Kartika Sari ${ }^{3}$ \\ ${ }^{1}$ Jurusan Matematika, Fakultas MIPA - Universitas Udayana [suryawan19@ gmail.com] \\ ${ }^{2}$ Jurusan Matematika, Fakultas MIPA - Universitas Udayana [taritastrawati@yahoo.com] \\ ${ }^{3}$ Jurusan Matematika, Fakultas MIPA - Universitas Udayana [sari_kartika@yahoo.co.id] \\ ${ }^{\S}$ Corresponding Author
}

\begin{abstract}
Companies which engaged in production activities such as Ramadhan Bakery would want optimal profit in their every production. The aim of this study was to find optimal profit and optimal combination of bread production (original chocolate bread, extra chocolate bread, rounding chocolate bread and mattress chocolate bread) that was produced by Ramadhan Bakery by applying Branch and Bound Algorithm method. Branch and Bound Algorithm is one method to solve Integer Programming's problems other than Cutting Plane method. Compared with Cutting Plane method, Branch and Bound Algorithm method is more effective in determining the optimal value. As the result of this study showed that to get optimal profit, Ramadhan Bakery should produce 360 pcs of original chocolate bread, 300 pcs of extra chocolate bread, 306 pcs of rounding chocolate bread and 129 pcs of mattress chocolate bread with optimal profit amounts Rp. 1.195.624,00.. The profit will increase amounts $25,2 \%$ than before.
\end{abstract}

Keywords: Branch and Bound Algorithm, Optimal Profit, Optimize.

\section{PENDAHULUAN}

Pemrograman Integer (Integer Programming) adalah pemrograman linear dengan variabel berupa bilangan bulat atau integer (Taha, 1997). Branch and Bound Algorithm merupakan salah satu metode yang dapat menyelesaikan kasus Pemrograman Integer. Metode ini membagi permasalahan menjadi sub-masalah (branching) yang mengarah ke solusi dengan membentuk sebuah struktur pohon pencarian dan melakukan pembatasan (bounding) untuk mencapai solusi optimal (Frederic, S. Hillier \& Lieberman, 1990). Prosedur algoritma Branch and Bound dilakukan secara berulang hingga membentuk pohon pencarian (search tree) dan dilakukan proses pembatasan (bounding) dengan menentukan batas atas (upper bound) dan batas bawah (lower bound) dalam mencari solusi optimal (Frederic, S. Hillier \& Lieberman, 1990). Perbedaan Branch and Bound Algorithm dengan pemrograman linear adalah Branch and Bound Algorithm dapat digunakan dalam menyelesaikan kasus optimalisasi dengan nilai variabel optimal harus berupa bilangan bulat, sedangkan pada pemrograman linear memungkinkan nilai variabel optimalnya tidak berupa bilangan bulat (Taha, 1997).

Selain Branch and Bound Algorithm terdapat metode lain yang dapat menyelesaikan kasus pemrograman bilangan bulat (integer) yaitu algoritma bidang pemotong atau biasa disebut algoritma Cutting Plane. Di antara kedua metode tersebut, Branch and Bound Algorithm adalah metode yang nilai pemecahannya lebih optimal dibandingkan dengan algoritma Cutting Plane dari segi hasil pemecahannya (Taha, 1997). Algoritma Cutting Plane terbukti tidak efektif dalam memecahkan masalah-masalah pemrograman integer tanpa bergantung pada ukurannya. Pada Algoritma Cutting Plane sering terjadi perubahan acak dalam urutan batasan sehingga membuat sebuah 
masalah yang mudah dari segi perhitungan menjadi sebuah masalah yang sangat rumit untuk diselesaikan (Taha, 1997). Beberapa kasus optimasi yang dapat diselesaikan dengan Branch and Bound Algorithm antara lain pengoptimalan jumlah produksi dan Travelling Salesman Problem (TSP).

Muliawan (20111) menerapkan Branch and Bound Algorithm pada kasus Travelling Salesman Problem (TSP) untuk menyelesaikan solusi optimal jalur pendistribusian bahan bangunan. Selain itu Alamnuariputri (2013) juga menggunakan Branch and Bound Algorithm dan algoritma Cutting Plane pada pengoptimalan jumlah produksi produk saniter. Sebagai hasil dari penelitian Alamnuariputri diperoleh bahwa solusi bulat optimum jumlah produksi produk saniter yang dihasilkan dari Branch and Bound Algorithm lebih maksimal dibandingkan algoritma Cutting Plane. Lebih lanjut lagi Margiyani (2014) juga mengaplikasikan Branch and Bound Algorithm pada kasus Travelling Salesman Problem (TSP) dan berhasil mencari rute terpendek yang dapat dilalui mobil pemadam kebakaran di Kota Yogyakarta.

Kasus lain sehubungan dengan pengoptimalan jumlah produksi yang nilai optimumnya bilangan bulat salah satunya adalah pengoptimalan jumlah produksi roti. Ramadhan Bakery adalah sebuah perusahaan di kota Denpasar yang memproduksi berbagai jenis roti setiap harinya. Tentunya dalam satu hari perusahaan harus bisa mengoptimalkan produksi roti yang akan dijualnya untuk mendapatkan keuntungan yang maksimal. Selama ini Ramadhan Bakery hanya mengirangira jumlah produksi roti yang akan diproduksi. Oleh karena itu akan diterapkan Branch and Bound Algorithm untuk mendapatkan jumlah produksi optimum roti di Ramadhan Bakery per harinya sehingga diperoleh keuntungan maksimal.

\section{METODE PENELITIAN}

Sumber data yang digunakan dalam penelitian ini merupakan data sekunder dari
Ramadhan Bakery yang berupa data input dan output perusahaan pada periode 1 Januari 2016 sampai dengan 31 Agustus 2016. Ada 4 variabel yang yang digunakan dalam penelitian ini yaitu banyaknya roti coklat biasa per pes $\left(x_{1}\right)$, banyaknya roti coklat ekstra per pcs $\left(x_{2}\right)$, banyaknya roti bulat rasa coklat per pes $\left(x_{3}\right)$, dan banyaknya roti kasur rasa coklat per pcs $\left(x_{4}\right)$. Untuk menentukan jumlah optimal produksi roti per hari pada Ramadhan Bakery dengan menggunakan Branch and Bound Algorithm. Langkah-langkah Branch and Bound Algorithm dalam kasus optimasi dapat dijelaskan sebagai berikut (Siang, 2011).

1. Menyelesaikan LP dengan metode simpleks.

2. Jika variabel basis yang diharapkan bernilai bulat telah mencapai nilai berupa bilangan bulat, maka solusi bulat optimum telah tercapai.

3. Jika variabel basis yang diharapkan bernilai bulat belum mencapai nilai yang berupa bilangan bulat, maka nilai solusi yang masih berupa bilangan pecahan harus dicabangkan ke dalam sub-sub masalah (branching). Misalkan variabel dari nilai solusi optimum yang belum berupa bilangan bulat adalah $x_{j}$ dengan $i_{1}<x_{j}<$ $i_{2}$ ( $i_{1}$ dan $i_{2}$ merupakan 2 bilangan bulat berurutan). Pencabangan dilakukan menjadi 2 sub masalah baru yaitu $x_{j} \leq i_{1}$ untuk cabang kiri dan $x_{j} \geq i_{2}$ untuk cabang kanan. Perhitungan yang diselesaikan terlebih dahulu adalah pencabangan di sisi sebelah kiri. Bila terdapat lebih dari satu variabel pecahan pada solusi optimum, maka pilih variabel dengan nilai pecahan terbesar untuk dicabangkan terlebih dahulu.

4. Nilai solusi optimum kontinu fungsi tujuan ditetapkan sebagai batas atas pada setiap sub-masalah. Batas bawah adalah pemecahan bulat pertama yang didapatkan melalui tahap pencabangan yang menjadi patokan kapan pencabangan dapat dihentikan (misalkan $X^{*}$ dengan nilai fungsi $f\left(X^{*}\right)$ ). Batas bawah belum tentu 
merupakan penyelesaian optimal masalah mula-mula.

5. Setiap pencabangan diselesaikan dengan metode simpleks.

6. Jika salah satu atau kedua bagian tersebut menghasilkan solusi yang bulat, maka bagian tersebut dihentikan dan ditetapkan sebagai batas bawah. Jika kedua masalah belum menghasilkan solusi yang bulat, maka dipilih salah satu bagian yang memiliki nilai fungsi tujuan yang lebih besar untuk kembali dicabangkan. Selesaikan pencabangan dengan metode simpleks sampai ditemukan batas bawah (langkah 5).

7. Setelah ditemukan batas bawah, lakukan pencabangan pada variabel yang belum berupa bilangan bulat pada solusi optimum. $\left(X_{a}\right)$ adalah solusi optimum lain yang didapat setelah ditemukannya batas bawah (berupa variabel bulat atau tidak).

8. Pencabangan dihentikan apabila solusi optimum lain $\left(X_{a}\right)$ memiliki nilai fungsi lebih besar dari nilai fungsi batas bawah $\left(f\left(X_{a}\right)>f\left(X^{*}\right)\right)$ pada kasus maksimasi dan jika solusi optimum lain $\left(X_{a}\right)$ memiliki nilai fungsi lebih kecil dari nilai fungsi batas bawah $\left(f\left(X_{a}\right)<f\left(X^{*}\right)\right)$ pada kasus minimasi. Jika pencabangan dihentikan dengan solusi optimum lain $\left(X_{a}\right)$ yang belum berupa bilangan bulat, maka batas bawah akan ditetapkan sebagai solusi bulat optimum. Pencabangan juga dihentikan apabila pemecahan menghasilkan nilai yang tidak layak (nilai variabel basis pada kolom solusi bernilai negatif) dan apabila terjadi maka batas bawah ditetapkan sebagai solusi bulat optimum.

9. Jika ditemukan solusi optimum lain $\left(X_{a}\right)$ yang bernilai bulat, maka lakukan pembandingan dengan batas bawah, lalu dipilih solusi bulat optimum yang memiliki nilai paling optimal atau menghasilkan nilai $\mathrm{Z}$ yang lebih optimal (bernilai lebih besar untuk kasus maksimasi dan bernilai lebih kecil untuk kasus minimasi).

10. Jika sudah ditemukan nilai optimum yang memenuhi syarat integer maka nilai tersebut dibandingan dengan nilai keuntungan produksi sebelumnya yang biasa dilakukan perusahaan per harinya yaitu Rp. 954.504.

\section{HASIL DAN PEMBAHASAN}

\subsection{Variabel Keputusan}

Langkah awal dalam memodelkan suatu masalah yaitu dengan menentukan variabelvariabel yang berpengaruh di dalamnya. Bahan yang digunakan dalam pembuatan masingmasing jenis roti dapat dilihat pada Tabel 1 .

Tabel 1. Data Penelitian Bahan (dalam gr per pes roti).

\begin{tabular}{|l|l|l|l|l|r|}
\hline $\begin{array}{c}\text { Bahan yang } \\
\text { dibutuhkan }\end{array}$ & $\begin{array}{c}\text { Roti coklat } \\
\text { biasa per pcs } \\
(\mathrm{gr})\end{array}$ & $\begin{array}{c}\text { Roti coklat } \\
\text { ekstra per pcs } \\
(\mathrm{gr})\end{array}$ & $\begin{array}{c}\text { Roti bulat } \\
\text { coklat per } \\
\text { pcs }(\mathrm{gr})\end{array}$ & $\begin{array}{c}\text { Roti kasur } \\
\text { coklat per pcs } \\
(\mathrm{gr})\end{array}$ & $\begin{array}{c}\text { Persediaan } \\
\text { per hari (gr) }\end{array}$ \\
\hline Tepung terigu & 10 & 30 & 22.5 & 120 & 35000 \\
\hline Ragi & 1.5 & 4 & 3 & 15 & 6000 \\
\hline Susu bubuk & 1.5 & 5 & 3.4 & 20 & 6000 \\
\hline Gula pasir & 3 & 10 & 6 & 28 & 12000 \\
\hline Margarin & 3.5 & 11 & 7.5 & 35 & 15000 \\
\hline Coklat Bubuk & 1.25 & 12.15 & 3 & 25 & 10000 \\
\hline Garam & 0.5 & 2.5 & 1.25 & 12 & 5000 \\
\hline Kuning telur & 10 & 32 & 20.25 & 82 & 30000 \\
\hline
\end{tabular}

keterangan :

Berdasarkan Tabel 1 variabel keputusan dalam penelitian ini adalah $x_{i}=$ banyak roti jenis $i$ yang diproduksi setiap harinya $(i=1,2,3,4)$ $x_{1}$ adalah banyaknya roti coklat biasa yang diproduksi setiap hari.

$x_{2}$ adalah banyaknya roti coklat ekstra yang diproduksi setiap hari. 
$x_{3}$ adalah banyaknya roti bulat rasa coklat yang diproduksi setiap hari.

$x_{4}$ adalah banyaknya roti kasur rasa coklat yang diproduksi setiap hari.

\subsection{Batasan untuk Membuat Tiap Jenis Roti}

Adapun kendala yang ditemukan dalam pembuatan tiap jenis roti antara lain :

\section{Batasan Penggunaan Bahan Tepung \\ Terigu}

Penggunaan bahan tepung terigu dapat dinyatakan dalam pertidaksamaan:

Keterangan :

$$
\sum_{i=1}^{n} p_{i} x_{i} \leq P T_{i}
$$

$p_{i}=$ banyaknya tepung terigu yang digunakan untuk membuat roti $i$,

$x_{i}=$ banyak roti jenis $i$ yang diproduksi setiap hari $(i=1,2,3,4)$

$P T_{i}=$ persediaan terigu sebagai bahan roti dalam 1 hari.

Berdasarkan Tabel 1, batasan untuk bahan tepung terigu adalah sebagai berikut $10 x_{1}+30 x_{2}+22.5 x_{3}+120 x_{4} \leq 35000$

\section{Batasan Penggunaan Bahan Ragi}

Penggunaan bahan ragi dapat dinyatakan dalam pertidaksamaan:

$$
\sum_{i=1}^{n} q_{i} x_{i} \leq P R_{i}
$$

Keterangan :

$q_{i}=$ banyaknya ragi yang diperlukan untuk membuat roti $i$,

$x_{i}=$ banyak roti jenis $i$ yang diproduksi setiap hari $(i=1,2,3,4)$

$P R_{i}=$ persediaan ragi sebagai bahan roti dalam 1 hari.

Berdasarkan Tabel 1, batasan untuk bahan ragi adalah sebagai berikut

$1.5 x_{1}+4 x_{2}+3 x_{3}+15 x_{4} \leq 6000$

\section{Batasan Penggunaan Bahan Susu Bubuk}

Penggunaan bahan susu bubuk dapat dinyatakan dalam pertidaksamaan:

$$
\sum_{i=1}^{n} r_{i} x_{i} \leq P S_{i}
$$

Keterangan :

$r_{i}=$ banyaknya susu bubuk yang digunakan untuk membuat roti $i$,

$x_{i}=$ banyak roti jenis $i$ yang diproduksi setiap hari $(i=1,2,3,4)$

$P S_{i}=$ persediaan susu bubuk sebagai bahan roti dalam 1 hari.

Berdasarkan Tabel 1, batasan untuk bahan susu bubuk adalah sebagai berikut

$$
1.5 x_{1}+5 x_{2}+3.4 x_{3}+20 x_{4} \leq 6000
$$

\section{Batasan Penggunaan Bahan Gula Pasir}

Penggunaan bahan gula pasir dapat dinyatakan dalam pertidaksamaan:

$$
\sum_{i=1}^{n} s_{i} x_{i} \leq P G_{i}
$$

Keterangan :

$s_{i}=$ banyaknya gula pasir yang digunakan untuk membuat roti $i$,

$x_{i}=$ banyak roti jenis $i$ yang diproduksi setiap hari $(i=1,2,3,4)$

$P G_{i}=$ persediaan gula pasir sebagai bahan roti dalam 1 hari.

Berdasarkan Tabel 1, batasan untuk bahan gula pasir adalah sebagai berikut

$3 x_{1}+10 x_{2}+6 x_{3}+28 x_{4} \leq 12000$

\section{Batasan Penggunaan Bahan Margarin}

Penggunaan bahan margarin dapat dinyatakan dalam pertidaksamaan:

$$
\sum_{i=1}^{n} t_{i} x_{i} \leq P M_{i}
$$

Keterangan :

$t_{i}=$ banyaknya margarin yang digunakan untuk membuat roti $i$,

$x_{i}=$ banyak roti jenis $i$ yang diproduksi setiap hari $(i=1,2,3,4)$

$P M_{i}=$ persediaan margarin sebagai bahan roti dalam 1 hari. 
Berdasarkan Tabel 1, batasan untuk bahan margarin adalah sebagai berikut

$3.5 x_{1}+11 x_{2}+7.5 x_{3}+35 x_{4} \leq 15000$

\section{Batasan Penggunaan Bahan Coklat \\ Bubuk}

Penggunaan bahan coklat bubuk dapat dinyatakan dalam pertidaksamaan:

$$
\sum_{i=1}^{n} u_{i} x_{i} \leq P C_{i}
$$

Keterangan :

$u_{i}=$ banyaknya coklat bubuk yang digunakan untuk membuat roti $i$,

$x_{i}=$ banyak roti jenis $i$ yang diproduksi setiap hari $(i=1,2,3,4)$

$P C_{i}=$ persediaan coklat sebagai bahan roti dalam 1 hari.

Berdasarkan Tabel 1, batasan untuk bahan coklat adalah sebagai berikut

$1.25 x_{1}+12.15 x_{2}+3 x_{3}+25 x_{4} \leq 10000$

\section{Batasan Penggunaan Bahan Garam}

Penggunaan bahan garam dapat dinyatakan dalam pertidaksamaan:

$$
\sum_{i=1}^{n} v_{i} x_{i} \leq P D_{i}
$$

Keterangan :

$v_{i}=$ banyaknya garam yang digunakan untuk membuat roti $i$

$x_{i}=$ banyak roti jenis $i$ yang diproduksi setiap hari $(i=1,2,3,4)$

$P D_{i}=$ persediaan garam sebagai bahan roti dalam 1 hari.

Berdasarkan Tabel 1, batasan untuk bahan garam adalah sebagai berikut

$0.5 x_{1}+2.5 x_{2}+1.25 x_{3}+12 x_{4} \leq 5000$

\section{Batasan Penggunaan Bahan Kuning Telur}

Penggunaan bahan kuning telur dapat dinyatakan dalam pertidaksamaan:

$$
\sum_{i=1}^{n} w_{i} x_{i} \leq P K_{i}
$$

Keterangan :

$w_{i}=$ banyaknya kuning telur yang digunakan untuk membuat roti $i$,

$x_{i}=$ banyak roti jenis $i$ yang diproduksi setiap hari $(i=1,2,3,4)$

$P K_{i}=$ persediaan kuning telur sebagai bahan roti dalam 1 hari.

Berdasarkan Tabel 1, batasan untuk bahan kuning telur adalah sebagai berikut

$10 x_{1}+32 x_{2}+20.25 x_{3}+82 x_{4} \leq 30000$

\section{Batasan Target Produksi}

Selain batasan pada bahan, target produksi yang ditetapkan perusahaan juga diperhatikan. Jumlah produksi roti per hari adalah sebagai berikut :

Tabel 2. Target Produksi Masing-masing Jenis Roti

\begin{tabular}{|l|l|c|}
\hline No & Jenis Roti & $\begin{array}{l}\text { Target Produksi } \\
\text { Roti per hari } \\
\text { (per pcs) }\end{array}$ \\
\hline 1 & Roti coklat biasa & 300 \\
\hline 2 & Roti coklat ekstra & 200 \\
\hline 3 & Roti bulat rasa coklat & 250 \\
\hline 4 & $\begin{array}{l}\text { Roti kasur rasa } \\
\text { coklat }\end{array}$ & 100 \\
\hline
\end{tabular}

Pertidaksamaan yang dibentuk yaitu

dengan:

$$
x_{i} \geq B_{i}
$$

$B_{i}=$ target roti yang dihasilkan dalam sehari.

Berdasarkan Tabel 2, dapat disusun batasan target minimal produksi

$$
\begin{aligned}
& x_{1} \geq 300 \\
& x_{2} \geq 200 \\
& x_{3} \geq 250 \\
& x_{4} \geq 100
\end{aligned}
$$

\section{Batasan Produksi Maksimal}

Adapun batasan produksi maksimal yang membatasi produksi roti per harinya agar tidak melebihi kapasitas tempat penyimpanan yang 
ada. Produksi maksimal roti per hari adalah sebagai berikut

Tabel 3 Batasan Produksi Maksimal.

\begin{tabular}{|l|l|c|}
\hline No & Jenis Roti & $\begin{array}{l}\text { Produksi } \\
\text { Maksimal Roti } \\
\text { per hari (per } \\
\text { pcs) }\end{array}$ \\
\hline 1 & Roti coklat biasa & 360 \\
\hline 2 & Roti coklat ekstra & 300 \\
\hline 3 & Roti bulat rasa coklat & 360 \\
\hline 4 & Roti kasur rasa coklat & 144 \\
\hline
\end{tabular}

Pertidaksamaan untuk batasan target produksi adalah

dengan:

$$
x_{i} \leq J_{i}
$$

$J_{i}=$ jumlah maksimal roti yang dapat diproduksi per harinya.

Berdasarkan Tabel 3, dapat disusun batasan produksi maksimal

$$
\begin{aligned}
& x_{1} \leq 360 \\
& x_{2} \leq 300 \\
& x_{3} \leq 360 \\
& x_{4} \leq 144
\end{aligned}
$$

\section{Biaya Pembuatan Roti}

Dalam menentukan model persamaan linear dari kasus Ramadhan Bakery, perlu diketahui biaya pembuatan roti. Berikut adalah tabel harga bahan pembuatan roti per gr per pes roti.

Tabel 4. Harga Bahan Pembuatan Roti (dalam gr per satu pcs roti)

\begin{tabular}{|l|l|l|}
\hline No & $\begin{array}{l}\text { Bahan yang } \\
\text { dibutuhkan }\end{array}$ & Rupiah/gr \\
\hline 1 & Tepung terigu & 9.7 \\
\hline 2 & Ragi & 61 \\
\hline 3 & Susu bubuk & 24.15 \\
\hline 4 & Gula pasir & 13.453 \\
\hline 5 & Margarin & 36.034 \\
\hline 6 & Coklat & 58 \\
\hline 7 & Garam & 10.5 \\
\hline 8 & Kuning telur & 15 \\
\hline
\end{tabular}

Berdasarkan Tabel 1 dan Tabel 4 dapat diketahui biaya pembuatan roti per pcs.
Tabel 5. Biaya Pembuatan Tiap Jenis Roti (per pcs).

\begin{tabular}{|l|l|r|}
\hline No & Jenis Roti & $\begin{array}{l}\text { Biaya } \\
\text { Pembuatan } \\
\text { Roti (Rp) }\end{array}$ \\
\hline 1 & Roti coklat biasa & 618.953 \\
\hline 2 & Roti coklat ekstra & 2397.604 \\
\hline 3 & Roti bulat rasa coklat & 1325.208 \\
\hline 4 & Roti kasur rasa coklat & 7005.874 \\
\hline
\end{tabular}

Perlu diketahui harga jual yang ditetapkan oleh perusahaan adalah sebagai berikut

Tabel 6. Harga Jual Tiap Jenis Roti

\begin{tabular}{|l|l|r|}
\hline No & Jenis Roti & $\begin{array}{l}\text { Harga Jual } \\
\text { Roti (Rp) }\end{array}$ \\
\hline 1 & Roti coklat biasa & 1000 \\
\hline 2 & Roti coklat ekstra & 4000 \\
\hline 3 & Roti bulat rasa coklat & 2000 \\
\hline 4 & Roti kasur rasa coklat & 10000 \\
\hline
\end{tabular}

\subsection{Fungsi Tujuan}

Tujuan yang ingin dicapai oleh perusahaan adalah memperoleh keuntungan maksimum setiap jenis produk roti rasa coklat. Hal ini dapat diperoleh dari selisih antara harga jual produk dengan biaya yang dikeluarkan. Untuk keuntungan roti coklat biasa didapat dari selisih antara harga jual roti coklat biasa pada Tabel 6 yaitu Rp. 1000 dengan biaya pembuatan roti coklat biasa pada Tabel 5yaitu Rp. 618.953 dan menghasilkan nilai keuntungan Rp. 381.047. Untuk keuntungan roti jenis yang lain dapat dilihat pada Tabel 7.

Tabel 7. Keuntungan Roti per pcs.

\begin{tabular}{|l|l|r|}
\hline No & Jenis Roti & $\begin{array}{l}\text { Keuntungan roti } \\
\text { per pcs (Rp) }\end{array}$ \\
\hline 1 & Roti coklat biasa & 381.047 \\
\hline 2 & Roti coklat ekstra & 1602.396 \\
\hline 3 & $\begin{array}{l}\text { Roti bulat rasa } \\
\text { coklat }\end{array}$ & 674.792 \\
\hline 4 & $\begin{array}{l}\text { Roti kasur rasa } \\
\text { coklat }\end{array}$ \\
\hline
\end{tabular}


Dari Tabel 7 didapatkan fungsi tujuan untuk kasus ini yaitu

Maksimalkan

$$
\begin{gathered}
Y=381.047 x_{1}+1602.396 x_{2}+674.792 x_{3} \\
+2994.126 x_{4}
\end{gathered}
$$

Keuntungan optimal penjualan roti per harinya dapat dimodelkan sebagai berikut.

$$
Q=Y-L
$$

dengan :

$Q=$ keuntungan optimal roti per harinya.

$Y=$ nilai optimal yang didapat menggunakan Branch and Bound Algorithm.

$L=$ biaya yang dikeluarkan perusahaan untuk upah tenaga kerja per harinya.

Biaya upah tenaga kerja per hari $(L)$ adalah perkalian antara jumlah karyawan dengan gaji karyawan per hari. Pada perusahaan ini setiap pekerja mendapatan gaji sebesar Rp. 50.000 per harinya. Jumlah karyawan di perusahaan ini adalah 10 orang, namun yang mendapat bagian untuk mengerjakan jenis roti yang diteliti adalah 3 orang. Jadi per harinya perusahaan mengeluarkan biaya sebesar $3 \times$ Rp. 50.000 yaitu Rp. 150.000 .

\subsection{Menghitung Nilai Optimum dari Model}

Berdasarkan batasan dan fungsi tujuan yang telah disusun, akan dihitung nilai optimal (memaksimalkan) dari model yang dibentuk yaitu

Fungsi objektif ;

$$
\begin{gathered}
Y=381.047 x_{1}+1602.396 x_{2}+674.792 x_{3} \\
+2994.126 x_{4}
\end{gathered}
$$

Kendala ;

$$
\begin{aligned}
& 10 x_{1}+30 x_{2}+22.5 x_{3}+120 x_{4} \leq 35000 \\
& 1.5 x_{1}+4 x_{2}+3 x_{3}+15 x_{4} \leq 6000 \\
& 1.5 x_{1}+5 x_{2}+3.4 x_{3}+20 x_{4} \leq 6000 \\
& 3 x_{1}+10 x_{2}+6 x_{3}+28 x_{4} \leq 12000 \\
& 3.5 x_{1}+11 x_{2}+7.5 x_{3}+35 x_{4} \leq 15000 \\
& 1.25 x_{1}+12.15 x_{2}+3 x_{3}+25 x_{4} \leq 10000 \\
& 0.5 x_{1}+2.5 x_{2}+1.25 x_{3}+12 x_{4} \leq 5000 \\
& 10 x_{1}+32 x_{2}+20.25 x_{3}+82 x_{4} \leq 30000 \\
& 300 \leq x_{1} \leq 360 \\
& 200 \leq x_{2} \leq 300 \\
& 250 \leq x_{3} \leq 360 \\
& 100 \leq x_{4} \leq 144
\end{aligned}
$$

$x_{1}, x_{2}, x_{3}, \mathrm{x}_{4} \in \mathrm{Z}$

Menggunakan bantuan software QSB 2.0 didapat nilai optimal Branch and Bound Algorithm melalui dua pencabangan adalah $Y=1210624$ dengan $x_{1}=360, x_{2}=300$, $x_{3}=306$, dan $x_{4}=129$.

Kemudian dihitung keuntungan optimal roti per harinya $(Q)$ yaitu

$$
\begin{aligned}
& Q=1210624-150000 \\
& Q=1195624
\end{aligned}
$$

Dapat didefinisikan dengan memproduksi roti coklat biasa sebanyak 360 pcs, roti coklat ekstra sebanyak 300 pcs, roti bulat rasa coklat sebanyak 306 pcs dan roti kasur rasa coklat sebanyak 129 pcs per hari perusahaan mendapatkan keuntungan maksimal sejumlah Rp. 1.195.624. Jumlah produksi sebelumnya yang dilakukan oleh perusahaan yang memproduksi roti coklat biasa sebanyak 320 pcs, roti coklat ekstra sebanyak 300 pcs, roti bulat coklat sebanyak 300 pcs, dan roti kasur coklat sebanyak 100 pcs dengan keuntungan sebesar Rp. 954.504 per harinya. Jika dibandingkan perusahaan memperoleh keuntungan yang lebih besar jika mengoptimalkan produksi roti tersebut dengan menggunakan Branch and Bound Algorithm.

\section{KESIMPULAN}

Penerapan Branch and Bound Algorithm dalam mencari keuntungan optimal dan kombinasi produksi per harinya menghasilkan keuntungan Rp. 1.195.624 dengan jumlah produksi roti coklat biasa sebanyak 360 pcs, roti coklat ekstra sebanyak 300 pcs, roti bulat rasa coklat sebanyak 306 pes dan roti kasur rasa coklat sebanyak 129 pcs. Sementara keuntungan perusahaan Ramadhan Bakery sebelumnya dengan asumsi semua produksi habis terjual adalah Rp. 954.504. Dengan demikian terjadi peningkatan keuntungan sebesar 25,2 \% melalui perhitungan dengan menerapkan Branch and Bound Algorithm. 


\section{DAFTAR PUSTAKA}

Alamnuariputri, Y. A. (2013). Integer Programming Dengan Pendekatan Metode Banch and Bound dan Metode Cutting Plane untuk Optimasi Kombinasi Produk. Skripsi. Jurusan Matematika, Fakultas Matematika dan Ilmu Pengetahuan Alam, Universitas Brawijaya Malang, Indonesia.

Frederick, S. Hillier, \& Lieberman, G. (1990). Pengantar Riset Operasi Edisi Kelima. Jakarta: Erlangga.

Margiyani, S. (2014). Aplikasi Algoritma Branch and Bound untuk Optimasi Jalur Pemadam Kebakaran Kota Yogyakarta.
Skripsi. Program Studi Matematika, Fakultas Sains dan Teknologi, Universitas Islam Negeri Sunan Kalijaga, Yogyakarta.

Muliawan, I. G. (2011). Analisis Solusi Optimal Model Pendistribusian Menggunakan Metode Branch and Bound (Studi Kasus PT. CSA).Skripsi.Jurusan Matematika, Fakultas Matematika dan Ilmu Pengetahuan Alam, Universitas Udayana, Bali.

Siang, J. J. (2011). Riset Operasi dalam Pendekan Algoritmis. Yogyakarta: Penerbit Andi.

Taha, H. (1997). Operation Research an Introduction. New Jersey: Prentice-Hall International. 